\title{
Belgeo
}

Revue belge de géographie

\section{Changes in everyday mobility in England since the 1940s: A case study}

L'évolution de la mobilité quotidienne en Angleterre depuis les années 40 : étude de cas

Colin G. Pooley, Jean Turnbull and Mags Adams

\section{CpenEdition}

Electronic version

URL: http://journals.openedition.org/belgeo/12431

DOI: $10.4000 /$ belgeo. 12431

ISSN: 2294-9135

Publisher:

National Committee of Geography of Belgium, Société Royale Belge de Géographie

Printed version

Date of publication: 30 June 2005

Number of pages: $69-84$

ISSN: 1377-2368

\section{Electronic reference}

Colin G. Pooley, Jean Turnbull and Mags Adams, "Changes in everyday mobility in England since the 1940s: A case study", Belgeo [Online], 1-2 | 2005, Online since 27 October 2013, connection on 05 February 2021. URL: http://journals.openedition.org/belgeo/12431 ; DOI: https://doi.org/10.4000/ belgeo.12431

This text was automatically generated on 5 February 2021.

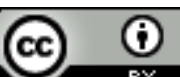

Belgeo est mis à disposition selon les termes de la licence Creative Commons Attribution 4.0 International. 


\section{Changes in everyday mobility in England since the 1940s: A case study}

L'évolution de la mobilité quotidienne en Angleterre depuis les années 40 : étude de cas

Colin G. Pooley, Jean Turnbull and Mags Adams

This research project was funded by the Economic and Social Research Council of the UK. Thanks to all the respondents who completed questionnaires and agreed to be interviewed. Thanks also to Cait Griffith for coding and data entry and to Geraldine Byrne for transcribing tapes.

\section{Why study everyday mobility?}

Geographical research on human mobility has concentrated mainly on residential migration, and especially on long-distance and involuntary movements that are highly visible: for instance, the movement of refugees and asylum seekers or the impact of high levels of out-migration on rural areas. Little attention has been directed at understanding the pattern, process and impacts of everyday mobility: movement such as travelling to school or to work, visits to friends and family, mobility for shopping or for leisure activities. In 1971 Wilbur Zelinsky argued that, in addition to changes in the extent and nature of residential movement, transition to an "advanced society" was also characterised by increases in population circulation. Although Zelinsky's hypothesis of the mobility transition has been extensively tested and criticised in the context of residential movement, there has been no research on long-run changes in all types of everyday mobility. There has been limited study of changes in the journey to school (Hillman, Adams and Whitelegg, 1990), but other research on mobility has focused on present-day action spaces and the mobility constraints faced by particular groups (Mathews, 1987; Smith, 1991; Mathews and Vujakovic, 1995; Wylie and Smith, 1996; Valentine, 1997). 
2 In the twenty-first century, the ability to travel freely on a daily basis is a taken-forgranted part of life in the developed world. It allows us to combine a large number of different activities in a busy day; to extend the area over which we seek work or in which our children go to school; and to visit friends and relatives, shop and pursue leisure activities in a wide range of different locations. However, for some, especially in London and other major cities, daily travel can take up a substantial amount of time; the financial, social and environmental costs of daily travel are considerable; and development of a credible sustainable transport policy is one of the greatest difficulties facing modern governments (Whitelegg, 1997; Docherty and Shaw, 2003).

3 Following Zelinsky's argument, it is usually assumed that both the amount of mobility and the distances over which people move increased substantially over the past century, and that everyday travel has become more complex. It is also obvious that the spread of faster transport modes to a wider range of people has enabled time-space convergence (where the barriers of distance are to some extent overcome by highspeed transport) and has encouraged time-space compression, where the whole process of life is speeded up as people fit an increasing number of activities in to a busy daily schedule and are forced to reconsider how they view space (Harvey 1989; Johnston et al., 2000). It can also be argued that, over the past century, there has been a new and increasing interaction between residential mobility and daily mobility, as people have to some extent been able to trade one for the other. Thus, whereas in the past if you changed your job to a new location you often also moved house, today it is possible to decide to stay in an attractive residential location but to commute over a longer distance (Pooley, 2003). However, there is little hard evidence to substantiate the nature and extent of such changes, even over the past 50 years. This paper provides a preliminary report on research that has explored changes in everyday mobility in Britain since the 1940s, and highlights some key elements of stability and change in the mobility process.

\section{Data and method}

4 Our research utilises a combination of questionnaire and interview methodologies to collect information about everyday mobility from four cohorts of respondents, but with the main emphasis on the use and interpretation of qualitative data. In the first phase of data collection attention was focused on factual, semi-quantitative, data collected through a structured questionnaire about the activities and mobility behaviour of respondents over fixed 12 month periods both now and in the past. In the second stage, an in-depth and focused interview probed the reasons for mobility decisions and the experiences of mobility in different time periods. To examine change over time four separate cohorts of respondents were identified: those in their 60s; those in their 30s; those age 17/18; and those age 10/11 (Table 1). Each cohort represented a different current life-cycle stage, and data were collected from each respondent with respect to their mobility at each of these life stages. Thus for those age 60-69 four time-slices of data were collected (mobility at age 10/11; age 17/18; age c35 and age c65), and for those age 10/11 just one (current mobility). Questionnaire data were coded and entered into an Access database for analysis. Interviews lasted up to 90 minutes, and all interviews have been fully transcribed, then coded and analysed using the text analysis programme Atlas ti. 
Table 1. Sample framework.

\begin{tabular}{|c|c|c|c|}
\hline Birth year & $\begin{array}{c}\text { Age at } \\
\text { Interview }\end{array}$ & Lifecycle stage & $\begin{array}{l}\text { Interview } \\
\text { periods }\end{array}$ \\
\hline $1932-41$ & $60-69$ & Retiring/retired/family left home & $\begin{array}{l}\text { Age 10/11 } \\
\text { Age 17/18 } \\
\text { Age } 30 \mathrm{~s} \\
\text { Age } 60 \mathrm{~s}\end{array}$ \\
\hline $1962-71$ & $30-39$ & Young/teenage family & $\begin{array}{l}\text { Age 10/11 } \\
\text { Age 17/18 } \\
\text { Age } 30 \text { s }\end{array}$ \\
\hline $1983-84$ & $17 / 18$ & End of secondary education/first job & $\begin{array}{l}\text { Age } 10 / 11 \\
\text { Age } 17 / 18\end{array}$ \\
\hline $1990-91$ & $10 / 11$ & Last year of primary education & Age 10/11 \\
\hline
\end{tabular}

Data reported in this paper relate to the urban area of Lancaster and Morecambe in North-west England. This small conurbation (population of 133,914 in Lancaster District in 2001) combines a market town and seaside resort in north Lancashire. To control for the impact of urban structure and intra-urban transport technologies on mobility, all respondents recruited to the study must have lived in the same urban area at each of the time slices for which information was collected. This placed considerable constraints on the selection of respondents. Those age 10/11 and 17/18 were recruited through local schools and colleges, and those in their 30s and 60s by contacting local employers and organisations, by advertising in the media, and through snowballing techniques. We aimed to recruit 20 respondents in each of the four cohorts. In fact data were collected for a total of 75 respondents in Lancaster and Morecambe, with the main shortfall amongst those in their 30s. As far as possible the sample has been structured to reflect the socio-economic characteristics of the area and there is an even gender balance of respondents. This gives a large sample from which to draw qualitative evidence though quantitative data must be interpreted with caution. Although each respondent recorded a large number of individual trips (for instance children aged 10/11 recorded over 2000 individual journeys), the fact that these are drawn from quite a small sample of individuals means that one or two respondents with unusual travel behaviour may distort the results.

6 As with all oral history there are problems of recall and memory that must be taken into account in analysis and interpretation. The most significant and original issue for this study is the likely effect of memory bias on the study of change over time. Thus, in comparing (for instance) mobility of a 10 year old in the 1940 s with that of a 10 year old today, we are comparing a child's recall of recent events with the recollections of a 65year old about a period over half a century earlier. The implications of this cannot be explored in detail in this paper, but our analysis of the transcripts suggests that such biases do not pose serious problems for data interpretation. 


\section{Analysis and interpretation}

\section{Introduction}

7 Analysis in this paper focuses on two questions. First, how has the mobility experience of children age 10/11 changed from the 1940s to the present and, second (and more briefly) how does everyday mobility vary over the life cycle. Attention is focused on four key issues: changes in the distance travelled and the time spent travelling; changes in modes of transport used; changes in the companions travelled with; and changes in the constraints on everyday mobility. Where quantitative evidence is used data mostly refer to the aggregate of all journeys recorded. This gives both a large sample size and provides an overview of total mobility. Results for selected types of trips are compared more briefly. There is always a danger in research of this sort that results either state the obvious or reinforce commonsense assertions. In this paper priority is given to identifying key elements of stability and change, arguing that given the rapid developments in transport technology, economic affluence and other aspects of urban society, stability in the pattern and process of mobility is in many ways more remarkable than change.

\section{Distance and time}

8 Whereas the mean distance travelled for all recorded everyday mobility by $10 / 11$ year olds increased significantly $\left(\mathrm{Chi}^{2} \rho 0.01\right)$ there was no significant change in the average amount of time spent travelling on everyday mobility (Tables 2,3). The mean distance travelled doubled from the 1940s to the 1970s, and increased slightly again to the 1990 s before dropping for children currently age 10/11. It is important to remember that this is a mean of all trips organised by category, with each type of trip recorded only once. It is not the mean of actual distance travelled as, clearly, short trips occurred much more frequently than longer journeys. We believe that the figure for the 1990s may be inflated slightly by the fact that a relatively high proportion of children in the $17 / 18$ cohort had parents with professional occupations, though if professional and managerial occupations are combined the occupational distribution of parents is similar between the cohorts. It is suggested that the relatively short mean distance for everyday mobility recorded for children born 1990-91 could reflect either increased constraints on the mobility of young children, or an indication that adults are curtailing the extent of their travel with children, possibly for environmental reasons or in response to an increasingly hectic lifestyle which leaves less time for travel for pleasure. This latter argument is to some extent borne out by changes in the distances travelled for different activities (Table 4). Whereas the mean distances travelled by children aged 10/11 to visit friends, go out to play or travel to school, three of the most common activities for such children, changed little from the 1940s to the present, remaining at around $1 \mathrm{~km}$ for each time period; the distance travelled to visit family and to undertake sporting activities (both journeys most likely to be undertaken with an adult) increased rapidly from the 1940s to the early 1990s, but then declined substantially in the early twenty-first century. 
Table 2. Distance travelled on all trips: Lancaster, all cohorts at age 10/11 (\%).

\begin{tabular}{lccccc}
\hline $\begin{array}{l}\text { Cohort } \\
\text { born: }\end{array}$ & $<500 \mathrm{~m}$ & $\begin{array}{r}500 \mathrm{~m}- \\
1499 \mathrm{~m}\end{array}$ & $\begin{array}{r}1500 \mathrm{~m}- \\
\mathbf{4 9 9 9 m}\end{array}$ & $\mathbf{5 0 0 0 \mathrm { m } +}$ & $\begin{array}{r}\text { Mean } \\
(\mathbf{k m})\end{array}$ \\
\hline $1990-91$ & 26.4 & 29.2 & 26.3 & 18.1 & 12.0 \\
$1983-84$ & 23.0 & 29.4 & 24.7 & 22.9 & 16.5 \\
$1962-71$ & 22.5 & 22.5 & 31.3 & 23.6 & 14.8 \\
$1932-41$ & 29.1 & 30.4 & 21.6 & 18.8 & 7.0 \\
All & 25.2 & 28.3 & 25.8 & 20.7 & 12.9 \\
$\mathrm{~N}$ & 504 & 566 & 515 & 413 & 1998 \\
\hline
\end{tabular}

SOURCE: EVERYDAY MOBILITY SAMPLE, 2001-2

Table 3. Time spent travelling on all trips: Lancaster, all cohorts at age 10/11 (\%).

\begin{tabular}{lccccc}
\hline $\begin{array}{l}\text { Cohort } \\
\text { born: }\end{array}$ & $<500 \mathrm{~m}$ & $\begin{array}{c}500 \mathrm{~m}- \\
1499 \mathrm{~m}\end{array}$ & $\begin{array}{c}1500 \mathrm{~m}- \\
\mathbf{4 9 9 9 m}\end{array}$ & $\mathbf{5 0 0 0 \mathrm { m } +}$ & $\begin{array}{r}\text { Mean } \\
(\mathrm{km})\end{array}$ \\
\hline $1990-91$ & 26.4 & 29.2 & 26.3 & 18.1 & 12.0 \\
$1983-84$ & 23.0 & 29.4 & 24.7 & 22.9 & 16.5 \\
$1962-71$ & 22.5 & 22.5 & 31.3 & 23.6 & 14.8 \\
$1932-41$ & 29.1 & 30.4 & 21.6 & 18.8 & 7.0 \\
All & 25.2 & 28.3 & 25.8 & 20.7 & 12.9 \\
$\mathrm{~N}$ & 504 & 566 & 515 & 413 & 1998 \\
\hline
\end{tabular}

SOURCE: EVERYDAY MOBILITY SAMPLE, 2001-2

9 The relative lack of change in the amount of time spent on travel is not surprising in that it simply reflects the ability of increasing numbers of people to switch to faster travel modes, and is borne out by other research on changes in the journey to work (Pooley and Turnbull, 1999). Again, we believe that the higher figure for the cohort age 17/18 may reflect a slight socio-economic bias in the sample but, overall, mean travel times were stable at around 30 minutes for all journeys. With regard to specific activities, the travel time for playing was very constant at around 9 minutes; visits to friends and the journey to school both varied slightly around a mean of 12 minutes (with the longest journeys in the 1940s); travel to sporting activity took on average 36 minutes with the shortest journeys in the 1940s, and visits to family took on average 66 minutes, with the longest journeys in the 1940s (Table 4). These figures clearly reflect a combination of quite complex changes in the speed of available transport and activity patterns. 
Table 4. Mean distance travelled and time spent travelling for specific activities: Lancaster, all cohorts at age $10 / 11$.

\begin{tabular}{|c|c|c|c|c|c|}
\hline $\begin{array}{l}\text { Cohort } \\
\text { born: }\end{array}$ & Play & Sport & Family & Friends & School \\
\hline \multicolumn{6}{|l|}{$1990-91$} \\
\hline Distance $(\mathrm{km})$ & 1.0 & 6.4 & 25.2 & 1.0 & 0.8 \\
\hline Time(min) & 9 & 30 & 42 & 9 & 8 \\
\hline \multicolumn{6}{|l|}{$1983-84$} \\
\hline Distance $(\mathrm{km})$ & 1.0 & 12.4 & 64.7 & 1.7 & 1.5 \\
\hline Time(min) & 10 & 45 & 74 & 16 & 15 \\
\hline \multicolumn{6}{|l|}{$1962-71$} \\
\hline Distance $(\mathrm{km})$ & 0.7 & 7.5 & 40.6 & 0.9 & 0.8 \\
\hline Time(min) & 7 & 36 & 61 & 7 & 10 \\
\hline \multicolumn{6}{|l|}{$1932-41$} \\
\hline Distance $(\mathrm{km})$ & 0.7 & 2.5 & 27.3 & 1.3 & 1.0 \\
\hline Time(min) & 9 & 23 & 94 & 17 & 15 \\
\hline \multicolumn{6}{|l|}{ All: } \\
\hline Distance $(\mathrm{km})$ & 0.9 & 10.0 & 41.5 & 1.3 & 1.0 \\
\hline Time(min) & 9 & 36 & 66 & 12 & 12 \\
\hline N & 154 & 223 & 211 & 143 & 79 \\
\hline
\end{tabular}

SOURCE: EVERYDAY MOBILITY SAMPLE 2001-2

\section{Travel modes and companions}

10 The significant $\left(\mathrm{Chi}^{2} \rho 0.001\right)$ changes in the modes of transport used for all everyday journeys are obvious and relatively easily explained (Table 5). The main distinction is between the 1940s and all later periods: walking and bus travel have declined whilst travel by car has increased substantially. However, perhaps of more interest, is the relative stability that underlies the above trends. For each time period walking accounted for at least $40 \%$ of all trips by 10 year olds ( $39.9 \%$ in the 1990 s), and even for those age 10/11 in 2000/01 walking was the single most important means of transport for this age group. In general, since the 1970s, the modal split for all trips for 10/11 year olds was $40 \%$ of trips by car and $40 \%$ on foot with the remaining $20 \%$ split between bus use, cycling and other transport forms (especially taxis). From another perspective, it can be suggested that both bus use and walking contributed approximately equally to the rise in car use between the 1940s and he 1970s, but because bus use started from a lower base the impact on this transport mode was much more dramatic. 
Table 5. Mode of transport used for all trips: Lancaster, all cohorts age 10/11 (\%).

\begin{tabular}{lccccc}
\hline $\begin{array}{l}\text { Cohort } \\
\text { born: }\end{array}$ & Car & Walk & Bus & Cycle & Other \\
\hline $1990-91$ & 41.8 & 43.6 & 1.5 & 5.3 & 7.8 \\
$1983-84$ & 43.1 & 39.9 & 3.0 & 4.9 & 9.1 \\
$1962-71$ & 35.9 & 44.6 & 7.3 & 6.1 & 6.1 \\
$1932-41$ & 3.3 & 63.9 & 25.2 & 1.0 & 6.6 \\
All & 33.7 & 46.5 & 7.6 & 4.5 & 7.7 \\
$\mathrm{~N}$ & 687 & 950 & 155 & 92 & 156 \\
\hline
\end{tabular}

SOURCE: EVERYDAY MOBILITY SAMPLE 2001-2

11 There have also been significant changes since the 1940s in the companions that children age 10/11 travelled with ( $\left.\mathrm{Chi}^{2} \rho 0.001\right)$. As with the mode of transport used, the main difference is between the 1940s and all later periods (Table 6). Children age 10/11 were much more likely to travel alone or with other children in the 1940s (accounting for over half of all trips), whereas from the 1970s onwards travel with adults accounted for some $70 \%$ or more of all everyday mobility. These data suggest that children were given more freedom to travel without adults in the 1940s, but that the pattern of having adult accompaniment for the majority of trips was firmly established by the 1970s (see qualitative evidence below). However, it should be emphasised that even in the 1940s journeys accompanied by adults were the single most important category, thus again pointing to some stability within the overall tend.

Table 6. Companions on all trips: Lancaster, all cohorts age 10/11 (\%).

\begin{tabular}{lccc}
\hline $\begin{array}{l}\text { Cohort } \\
\text { born: }\end{array}$ & Alone & Other children & Adults \\
\hline $1990-91$ & 7.0 & 23.1 & 69.9 \\
$1983-84$ & 4.8 & 19.5 & 75.8 \\
$1962-71$ & 5.3 & 18.4 & 76.3 \\
$1932-41$ & 21.1 & 31.0 & 47.9 \\
All & 8.7 & 22.6 & 68.7 \\
N & 176 & 459 & 1393 \\
\hline
\end{tabular}

SOURCE: EVERYDAY MOBILITY SAMPLE 2001-2

There is also a relatively stable gender split in both the modes of transport used and the extent to which children were accompanied (Tables 7,8). The differences are greatest, and are statistically significant $\left(\mathrm{Chi}^{2} \rho 0.05\right)$, for differences in mode of transport used by those born 1983/4 and 1962-71, and for travelling companions for those born 1990/91 and 1962-71. However the trends are consistent for each cohort when age 10/11: girls were more likely than boys to walk, and boys were most likely to 
cycle or (from the 1990s) travel by car. Girls were more likely to travel with adults and boys were more likely to travel with other children or alone. These data suggest that boys were given more freedom than girls (they were more likely to travel without adults and to cycle), but that girls (and probably their mothers) were more likely to use slower forms of transport (walking).

Table 7. Mode of transport used by gender for all trips: Lancaster, all cohorts age 10/11 (\%).

\begin{tabular}{lllll}
\hline & & \multicolumn{3}{c}{ Cohort born } \\
& $1990-91$ & $1983-84$ & $1962-71$ & $1932-41$ \\
\hline Car: & & & & \\
Boys & 44.3 & 45.0 & 34.7 & 3.2 \\
Girls & 39.5 & 41.2 & 37.0 & 3.3 \\
Walk: & 38.6 & 34.6 & 40.7 & 62.0 \\
Boys & 48.2 & 45.0 & 47.9 & 65.6 \\
Girls & & & & \\
Bus: & 1.9 & 4.2 & 5.4 & 25.7 \\
Boys & 1.2 & 1.9 & 8.9 & \\
Girls & & & & 1.6 \\
Cycle: & 7.0 & 5.5 & 13.2 & \\
Boys & 3.8 & 4.4 & 0.0 & \\
Girls & & & & 7.5 \\
Other: & 8.3 & 10.7 & 6.0 & \\
Boys & 7.4 & 7.5 & 6.3 & \\
Girls & & & & \\
\hline
\end{tabular}

SOURCE: EVERYDAY MOBILITY SAMPLE 2001-2

Table 8. Companions on all trips by gender. Lancaster, all cohorts age 10/11.

\begin{tabular}{|c|c|c|c|c|}
\hline & \multicolumn{4}{|c|}{ Cohort born } \\
\hline & $1990-91$ & $1983-84$ & $1962-71$ & $1932-41$ \\
\hline \multicolumn{5}{|l|}{ Alone: } \\
\hline Boys & 8.5 & 5.8 & 7.2 & 21.4 \\
\hline Girls & 5.6 & 3.8 & 3.6 & 20.8 \\
\hline \multicolumn{5}{|c|}{ Other children: } \\
\hline Boys & 26.9 & 19.1 & 22.8 & 33.5 \\
\hline Girls & 19.6 & 19.8 & 14.6 & 28.7 \\
\hline \multicolumn{5}{|l|}{ Adults: } \\
\hline Boys & 64.6 & 75.1 & 70.0 & 45.1 \\
\hline Girls & 74.8 & 76.4 & 81.8 & 50.5 \\
\hline
\end{tabular}

SOURCE: EVERYDAY MOBILITY SAMPLE 2001-2

\section{Changing mobility constraints}

13 The mobility patterns outlined above are obviously structured by a number of constraints and opportunities. To some extent all trips are affected by time and income constraints, but these will have mainly influenced the longer (and less frequent) trips. Short, frequent journeys such as journeys to play, to visit friends and to school are 
much more likely to have been influenced by a combination of parental constraints and the self-imposed boundaries of the children themselves. Most urban areas offer a variety of environments in which a 10 year old can play. These range from the formal (parks, gardens) to the informal but more challenging environments created by coasts, rivers, ponds, canals, fields, railway lines and derelict buildings. The Lancaster and Morecambe area contains all of these environments, most of which present obvious dangers to children as well as opportunities for exciting play. Qualitative evidence, collected through the in-depth interviews, is used to explore the extent to which constraints have been placed on children's play since the 1940s, and to assess how such factors have changed over time.

Two key themes emerge immediately from the qualitative evidence. First, within all four cohorts there is considerable variety in the experience of play and the amount of freedom that children were allowed. It is thus very hard to generalise, and for each time period it is possible to find examples of children who were restricted in their activities, but also examples of children who roamed quite freely. Second, there is an underlying stability in accounts of the experience of play with certain key themes emerging at each time period. These relate particularly to the importance of boundaries, the significance of traffic, the need for children to tell parents where they were going, the extent to which rules varied depending on the time of day and number of companions, and the impact of territorial rivalry between different groups of children. Some of these themes are illustrated in the extracts in Box 1.

Box 1: Qualitative evidence on the factors influencing the areas in which children aged 10/11 played

Cohort born 1990/91:

I know, I know where I'm allowed to go and where I'm not, because we're not/ some/there's a school field over there that children play on but we're not allowed to play on that, so we oughtn't go and play on there.

(R32, Female, 10/11 in 2001, Heysham)

Cohort born 1983/84:

Well sort of, I mean say we're getting to the summer holiday now it just/I don't know, we sort of spent the whole summer together so it, it depended what we wanted to do, we just used to sort of roam, run round Lancaster together really.

$\cdots$

Yea I mean as long as you know my mum always knew where I was going and you know I was getting there safely and, and it, it was fine. I mean I wouldn't ever be allowed to go out alone at night or anything but in the daytime when it was all sunny in summer and that we were alright to go out by ourselves. As long as there was the three of us it was fine.

(R7, Female, 10/11 in 1994, Lancaster)

Cohort born 1962-71: 
...we used to play football a lot. "Three and In", stand in the gatepost and kick the ball and if you let/got three past the goalie then you were in the goals. Probably walked, just walking round the block. We used to, actually there was a, there was a playground not too far from mum and dad's and we would go across there and play sometimes but that was/there was always, there was the rules that when that corner street light goes on you've got to come home and it/cause there was a street light that mum and dad could see from the front window, just on the corner of the, the two roads ...

(R21, Female, 10/11 in 1981, Lancaster)

\section{Cohort born 1932-41:}

The only thing that restricted you then was the main road at the top of the street and I wasn't allowed to go up to the main road on my own. Apart from that I could go anywhere and it was perfectly safe. And at the bottom of my street we had/it was called the "Clay Pit", and what it was was a lot of bricks, there used/there must have been a brick works around there at some time and we used, we could play down there. And there was also a lane that went through across two railways and it went through to Westgate and we were allowed to go up the lane and they considered the railway safe because there weren't many trains coming, and as long as we used the stiles and did it properly we could go up the lanes and no restrictions apart from the main road.

(R57, Female, 10/11 in 1950, Morecambe)

Many respondents from all cohorts mentioned that they had reasonably clearly defined areas in which they played regularly when they were 10/11, and that within these areas they were relatively unconstrained. Accounts differ (for all cohorts) in the extent to which these boundaries were clearly imposed by parents, or were constructed by children as areas in which they felt comfortable playing and which also conformed to adult expectations. The only noticeable trend is that the area defined in this way seems to have shrunk over time, with at least some children in the 1940s being able to roam freely over a wide area, whilst more recently most children have been confined to specific streets or parks. However, this is by no means universal as the testimony of R7 shows that in the 1990s she was able to roam freely over much of Lancaster at the age of 10 , though only in the daytime and when in the company of other children.

Most respondents, for all time periods, show an awareness of traffic dangers and suggest that to some extent traffic volumes affected where they played. Although road traffic was obviously much lighter in the 1940s than today, some respondents felt that their play was restricted by motor vehicles. For instance, R50 had to play on the back street to avoid a busy road in the 1940s. Almost all respondents in every time period also stressed the importance of telling parents (approximately) where they were going. This was part of the contract of being allowed a degree of freedom within a designated space. However, it can be suggested that the nature of this contract has subtly changed, with the expectation that parents know exactly where children are now much more firmly embedded than it was in the 1940s.

Very few respondents in any time period said that they experienced any real dangers whilst playing, however in each time period there are examples of specific events that 
led to some modification of behaviour, with subtle changes in how parents responded to these dangers. Thus, R52 recalls how a friend was drowned when he fell through ice on the Lancaster canal and after that playing by the canal was "frowned on" by his parents, though he clearly often ignored their warnings. In another incident in the 1940s, R111 explains how she and some female friends were stopped and asked to get into a car by a "funny man". The girls ran away and when her mother was informed she simply told the girls to avoid this man in future. The police were not informed and the girls' play space was only slightly modified. This theme of children negotiating dangers themselves with only minimal involvement of parents continued through the 1970s and into the 1990s. Thus R66, recounts how in the 1980s if he encountered "rough" kids from the local Council Estate he was told by his mother to simply move away from the area and not to get involved. However, he was not prevented from playing in this location. However, in 2001, R34 recounts how his parents prevented him going to the local park because "people hang around who we are not supposed to like" and "there's a boy running round with a pellet gun". Thus although these could be real dangers, this child is not allowed to experience and to negotiate them, but has his play space severely curtailed by his parents in a way that seemed not to occur even a decade ago.

Thus whilst there is a strong underlying stability in the experience of mobility for everyday play, and in the constraints affecting children age 10/11; the main change that has occurred appears to be the development of much greater parental control for the 2000/01 cohort. Compared even to the 1990s, children aged 10/11 are today given a smaller and more clearly specified area in which they can play freely, are monitored much more closely by their parents, and have their play curtailed at the first hint of danger. In contrast to children in the 1940s they never seem to actually experience danger, and thus do not have the opportunity to learn to negotiate and deal with such issues. The reasons for such changes cannot be fully explored in this paper, but it can be suggested that this reflects the much greater publicity given by both national and local media to a small number of specific events such as child abductions and related dangers. It is well established that fear of crime has more impact on behaviour than experience of crime, and it can be suggested that parental fears are increasingly restricting the everyday play of children in the twenty-first century (Valentine, 1997; Pain, 2000).

\section{Mobility over the life cycle}

Examination of changes in everyday mobility over the life cycle both reinforce some of the trends outlined above and introduce some specific life-cycle effects. These issues are outlined briefly in this paper for comparative purposes. For respondents now in their 60s, and asked about their mobility at four key life-cycle stages (age 10/11; age 17/18; age c35 and age c65), there has been a steady and statistically significant ( $\mathrm{Chi}^{2}$ $\rho 0.001$ in each case) increase in both the distance travelled and the time spent travelling (Table 9). Predictably, car use has increased significantly, especially from the 1970s, and both walking and bus use have declined (Table 10). These trends clearly reflect both general changes in society (increasing affluence, increased availability of cars) and more specific life cycle factors as first the constraints of family/young children and then of age affect mobility decisions. Specific and fairly obvious life-cycle effects are also apparent in changes in companions at different ages. 18 year olds are much more likely to travel alone, and adult women are much more likely than men to 
travel with children. Adult women also tend to travel over shorter distances but to use slower forms of transport. These trends are not surprising, but serve to underline the importance of societal factors in changing mobility for all groups within society.

Table 9. Changes over the life course in distance travelled and time spent travelling: all trips, respondents born 1932-41, Lancaster (\%).

\begin{tabular}{lcccc}
\hline & & & Age & \\
& $10 / 11$ & $17 / 18$ & $30 s$ & $60 s$ \\
\hline Distance: & & & & \\
$<500 \mathrm{~m}$ & 29.1 & 18.8 & 13.3 & 7.5 \\
$500 \mathrm{~m}-1499 \mathrm{~m}$ & 30.4 & 31.6 & 26.7 & 17.7 \\
$1500 \mathrm{~m}-4999 \mathrm{~m}$ & 21.6 & 26.4 & 30.4 & 39.7 \\
$5000 \mathrm{~m}+$ & 18.8 & 23.2 & 29.6 & 35.2 \\
Mean distance $(\mathrm{km})$ & 7.0 & 11.2 & 19.9 & 21.0 \\
Time: & & & & \\
$<10$ min & 20.5 & 14.6 & 11.7 & 9.1 \\
10-19.9 min & 37.6 & 37.0 & 45.4 & 36.9 \\
$20+$ min & 41.9 & 48.3 & 42.9 & 54.0 \\
Mean time $($ min $)$ & 30.3 & 35.4 & 59.0 & 52.0 \\
\hline
\end{tabular}

SOURCE: EVERYDAY MOBILITY SAMPLE 2001-2

Table 10. Changes over the life course in mode of transport used: all trips, respondents born 1932-41, Lancaster (\%).

\begin{tabular}{lcccc}
\hline & & & Age & \\
& $10 / 11$ & $17 / 18$ & $30 \mathrm{~s}$ & $60 \mathrm{~s}$ \\
\hline Mode & & & & \\
Car & 3.3 & 1.9 & 56.9 & 78.8 \\
Walk & 63.9 & 51.1 & 26.9 & 13.3 \\
Bus & 25.2 & 32.0 & 11.7 & 1.6 \\
Cycle & 1.0 & 6.8 & 0.0 & 0.2 \\
Other & 6.6 & 8.2 & 4.6 & 8.0 \\
\hline
\end{tabular}

SOURCE: EVERYDAY MOBILITY SAMPLE 2001-2

Qualitative evidence relating to changes over the life cycle also reinforces the interpretation that in recent years people have increasingly restricted their mobility because of media-fuelled fears of crime or disorder. As the testimony of R50 (Box 2) shows, when he was aged 10 though given a set of broad rules about where he could play, he was otherwise relatively unconstrained. Aged 17/18 he felt no fear though he was often out in Lancaster late at night. When aged circa 35 his mobility was constrained by the demands of a young family, though still felt unthreatened when walking in town. In contrast both R50 and his wife now find Lancaster increasingly threatening, especially in the evening when there are large numbers of people around. They recognise that this is probably irrational, and that it is fuelled by media reports of 
crime, but they still allow these fears to affect their behaviour and to restrict where and when they travel.

Box 2: Qualitative evidence on factors affecting mobility over the life course

Age 10/11 in1948 (Lancaster):

Well usual, we used to play/actually we were, we were told we had to play on the back street rather than the front street because traffic, although I mean traffic then was/but the buses used to come up and down Dale Street then, so we were always told to play on the back street. And of course we went onto the Bowerham waste ground because that was you know somewhere that/I think it used to be allotments at one time. ...Well, well we, we were allowed/yea we used to go up onto/the next street up from Dale Street is Prospect Street, we used to go up and play on there at one time I can remember, cause there used to be, there used to be air raid shelters on there before they were, before they were demolished. We were told to keep out of them, but I mean you used to play in these, you used to play in them.

Age 17/18 in 1955 (Lancaster):

No I think, I think when you're seventeen, eighteen you don't, you don't see the same as you would now perhaps. No I mean there, there were odd fights, you used to get odd fights in the dancehalls and, and outside afterwards you know, simple because people had had too much to drink or they'd be falling out over a girl or something like that. You never got any/I mean you never got anybody with knives and things like that you know. But yea there used to be fights, there used to be them.

Age mid-30s in 1970s (Lancaster):

Yea I, I don't think we felt unsafe walking the streets then, no. I mean we probably didn't go to the, to the places where the younger ones went then. I mean as you get, when you're in your thirties I mean you're ... I mean we were, we used to be a member of Lansil Sports Club then, you know the, the Social Club there ...So we'd perhaps go down there more than visit a pub in the town or something like that you know, so you probably weren't getting where the younger ones were getting. But you didn't/I don't think you feel/felt threatened.

Age mid-60s in 2001 (Lancaster):

I wouldn't like to be, and my wife is, is the same opinion, now we wouldn't like to be walking round Lancaster now on a Friday and Saturday night. I mean we've driven through a few times when we've, when we've been out, and you see all these young ones around here now you know. Em I mean it's full of students isn't it. Well I mean, I mean the students don't cause problems and it's very rare we get any trouble with the students, but the young locals ... I don't know. You, you/I think you feel more/I think you would feel threatened now you know. I mean you read all/I mean it's probably unfounded, I mean they tell you it's unfounded statistically ...I think when you get a bit older you tend to, to see more danger than 
perhaps that at you know eighteen you wouldn't bother about it would you. I mean we'd been out the other night, it's a fortnight ago, we went out with some friends and ...it was about well ten thirty, quarter to eleven when we came out, and we walked back up into the Square and it was absolutely heaving with, with youngsters. ... and you know my wife was glad we got in the car and away you know, yea.

\section{Conclusions}

This paper has examined broad changes in the everyday mobility of ten year olds in Lancaster and Morecambe, focusing on all types of mobility, and has assessed changes in the constraints imposed on travel for play. These trends have been briefly compared with changes over the life cycle. The main conclusion of this review is that whilst there are obvious and expected changes in patterns of everyday mobility, the degree to which there has been stability over time is especially striking. For many everyday activities the distances over which children travel have changed little, the time taken in travelling for everyday mobility has changed less, and gender differentials in both the mode of transport used and travel companions are stable over time. Examination of the constraints imposed on children's everyday mobility for play suggests that much the same factors have structured this mobility since the 1940s. The most significant change, seen both in the mobility of 10/11 year olds, and in changes over the life cycle, is the restrictive influence of increasing fear of crime.

Results that emphasise stability rather than change can be seen as rather unexciting. However we suggest that in this instance the opposite is the case. General models of mobility change, and common-sense assumptions about the impact of societal, economic and technological changes on mobility would all suggest that the last 60 years have been a period of unprecedented change in mobility. We are not suggesting that no changes have occurred. Clearly there has been a massive and significant increase in car use and people can now travel further and faster than ever before. However, the results of our analysis suggest that such changes have only a limited impact on most types of everyday mobility. We contend that most mundane but important types of mobility that sustain everyday life have continued to be structured by much the same factors for the past 60 years.

\section{BIBLIOGRAPHY}

DOCHERTY I. \& SHAW J. (eds.) (2003), A new deal for transport?, Oxford, Blackwell.

HARVEY D. (1989), The condition of postmodernity, Oxford, Blackwell.

HILLMAN M., ADAMS J. \& WHITELEGG J. (1990), One false move...: a study of children's independent mobility, London, PSI. 
JOHNSTON R. J. et al (2000), The dictionary of human geography, Oxford, Blackwell.

MATTHEWS M. (1987), “Gender, home range and environmental cognition”, Transactions of the Institute of British Geographers, New Series 12, London, Royal Geographical Society, pp. 43-56

MATTHEWS M. \& VUJAKOVIC P. (1995), "Private worlds and public spaces: mapping the environmental values of wheelchair users", Environment and Planning A, 27, London, Pion, pp. 1069-1083.

PAIN R. (2000), "Place, social relations and fear of crime: a review", Progress in Human Geography, 24, London, Arnold, pp. 365-87.

POOLEY C. (2003), "Mobility in the twentieth century: substituting commuting for migration", in GILBERT D., MATLESS D. AND SHORT B. (eds.), Geographies of British Modernity Oxford, Blackwell, pp. 80-96.

POOLEY C. \& TURNBULL J. (1999), “The journey to work: a century of change”, Area, 31, London, Royal Geographical Society, pp. 281-92.

SMITH G. (1991), "Grocery shopping patterns of the ambulatory urban elderly", Environment and Behaviour, London, Sage, 23, pp. 86-114.

VALENTINE G. “'Oh yes I can.' 'Oh no you can't': Children and parents' understanding of kids' competence to negotiate public space carefully", Antipode, 29, Oxford, Blackwell, pp. 65-89.

WHITELEGG J. (1997) Critical Mass: Transport Environment and Society in the Twenty-first Century, London, Pluto Press.

WYLLIE D. \& SMITH G. (1996), "Effects of extroversion on the routine spatial behaviour of middle adolescents", Professional Geographer, 48, Washington DC, Association of American Geographers, pp. 166-80.

ZELINSKY W. (1971), “The hypothesis of the mobility transition”, Geographical Review, 61, Worcester Mass, American Geographical Society, pp. 219-49.

\section{ABSTRACTS}

Everyday mobility is usually neglected in academic studies of population movement. This paper argues that it deserves greater attention, and that interaction between everyday mobility and residential migration is increasingly significant. Data on changes in everyday mobility since the 1940s have been collected through a series of surveys and in-depth interviews. This paper presents results from a case study of the everyday mobility of children aged 10/11 in Lancaster, NW England. Analysis of changes in the distance travelled, the time spent travelling, the mode of transport used and of travel companions shows that although there have been major and obvious changes in transport technology, and in the structure of economy and society, since the 1940s, many aspects of everyday mobility did not change. For many everyday activities the distances over which children travel have changed little, the time taken in travelling for everyday mobility has changed less, and gender differentials in both the mode of transport used and travel companions are stable over time. The most significant change is the restrictive influence of the fear of crime.

La mobilité quotidienne est généralement négligée dans les études universitaires du mouvement de la population. Cet article affirme qu'elle mérite plus d'attention, et que l'interaction entre mobilité quotidienne et migration résidentielle est de plus en plus significative. Les données concernant l'évolution de la mobilité quotidienne depuis les années quarante ont été rassemblées 
au moyen d'une série de sondages et d'entrevues en profondeur. Cet article présente les résultats d'une étude de cas de la mobilité quotidienne des enfants de dix à onze ans à Lancaster, au nordouest de l'Angleterre. L'analyse des changements en termes de distance parcourue, de durée, de moyen de transport utilisé et de compagnons de voyage, démontre qu'en dépit d'évidentes et significatives modifications dans la technologie des transports et la structure de l'économie et de la société depuis les années quarante, un grand nombre d'aspects de la mobilité quotidienne n'ont pas évolué. Pour beaucoup d'activités quotidiennes, les distances parcourues par les enfants ont peu changé, le temps qu'ils y consacrent encore moins, et les différences entre hommes et femmes, non seulement en ce qui concerne le mode de transport utilisé, mais aussi par rapport aux compagnons de voyage, sont restées stables au cours du temps. Le changement le plus significatif est l'influence restrictive de la peur du crime.

INDEX

Mots-clés: mobilité quotidienne, enfants, restrictions de la mobilité, Angleterre

Keywords: everyday mobility, children, mobility constraints, England

\section{AUTHORS}

COLIN G. POOLEY

Department of Geography, Lancaster University, Lancaster, UK, c.pooley@lancaster.ac.uk

JEAN TURNBULL

Department of Geography, Lancaster University, Lancaster, UK

MAGS ADAMS

Department of Geography, Lancaster University, Lancaster, UK 